\title{
PENERAPAN FUZZY INFERENCE SYSTEM METODE MAMDANI UNTUK PENENTUAN BESARAN PERSENTASE BEASISWA
}

\author{
Agus Sukoco ${ }^{1}$, Robby Yuli Endra ${ }^{2}$ \\ Teknik Informatika ${ }^{l}$ \\ Fakultas Ilmu Komputer -Universitas Bandar Lampung(UBL) \\ Handphone :0815-143-564-24 \\ Email:Agus.sukoco@ubl.ac.id / agussukoco16@gmail.com \\ Teknik Informatika ${ }^{2}$ \\ Fakultas Ilmu Komputer -Universitas Bandar Lampung(UBL) \\ Handphone : 0819-799-08-45 \\ Email : Capt.obbies@gmail.com / Robby.yuliendra@ubl.ac.id
}

\begin{abstract}
Abstrak
Untuk menjamin pendidikan yang bermutu, pemerintah wajib memberikan layanan dan kemudahan terhadap pendidikan tanpa adanya deskriminasi. Untuk menyelenggarakan pendidikan yang bermutu diperlukan biaya yang cukup besar Oleh karena itu bagi setiap peserta didik pada setiap satuan pendidikan berhak mendapatkan biaya pendidikan bagi mereka yang orang tuanya tidak mampu membiayai pendidikannya, dan berhak mendapatkan beasiswa bagi mereka yang berprestasi.

Penerapan Fuzzy Inference System (FIS) metode Mamdanidapat digunakan untuk pendukung keputusan dalam penentuan kelayakan beasiswa. Pada Fuzzy Inference System (FIS) metode Mamdaniuntuk memperoleh output diperlukan empat tahap, yaitu pembentukan himpunan fuzzy (Fuzzifikasi), pembentukan rules, aplikasi fungsi implikasi serta defuzzifikasi. Jenis penelitian ini merupakan jenis penelitian terapan, penelitian terapan ini merupakan suatu jembatan dari penelitian basic/murni diantara penelitian eksperimental. Teknik pengumpulan data yang dilakukan ada 3 metode yaitu Teknik Wawancara, Dokumentasi dan Observasi. Data yang didapatkan dari pihak marketing Fakultas Ilmu KomputerUniversitas Bandar Lampung. Tujuan dari penelitian ini adalah penerapan algoritma dan Fuzzy Inference System dengan Metode MAMDANI untuk penentuan kelayakan beasiswa mahasiswa baru, sehingga beasiswa diterima oleh calon mahasiswa tersebut tepat dan objektif. Hasil dari penelitian ini merupakan penerapan fuzzy inference system mamdani dilakukan dengan menggunakan 4 tahap yaitu pembentukan himpunan fuzzy, pembuatan aturan fuzzy(inference), fungsi implikasi dari setiap aturan dan Tahap terakhir adalah defuzifikasi. Dan Hasil lain dari penelitian ini bahwa fuzzy inference system mamdani dapat digunakan untuk penentuan kelayakan beasiswa sehingga beasiswa yang diberikan tersebut tepat dan objektif.
\end{abstract}

Keywords : Beasiswa, Metode MAMDANI,Mahasiswa

\section{PENDAHULUAN}

\subsection{Latar Belakang}

Pada lembaga pendidikan khususnya universitas banyak sekali beasiswa yang ditawarkan kepada mahasiswa yang berprestasi dan bagi mahasiswa yang kurang mampu. Seperti yang dituangkan dalam Undang-Undang Dasar 1945 pasal 31 (1) bahwa tiap-tiap warga Negara berhak mendapatkan pengajaran. Berdasarkan pasal tersebut, maka pemerintah Pusat dan daerah wajib memberikan layanan dan kemudahan, serta menjamin terselenggaranya pendidikan yang bermutu bagi setiap warga Negara tanpa diskriminasi. Untuk menyelenggarakan pendidikan yang bermutu diperlukan biaya pendidikan yang cukup besar. Oleh karena itu bagi setiap peserta didik pada setiap satuan pendidikan berhak mendapatkan biaya pendidikan bagi mereka yang orang tuanya tidak mampu membiayai pendidikannya, dan berhak mendapatkan beasiswa bagi mereka yang berprestasi.

Pendidikan merupakan suatu hal yang sangat penting untuk dapat bersaing didunia kerja. Rata-rata setiap lowongan kerja pendidikan yang dibutuhkan minimal diploma 3. Akan tetapi tidak semua orang dapat mengeyam pendidikan tinggi. Banyak orang yang ingin melanjutkan pendidikan yang lebih tinggi dan mempunyai, tetapi tidak mempunyai cukup biaya. Bahkan yang lebih menakjubkan ada seorang siswa yang sangat berprestasi tetapi karena tidak mempunyai 
biaya akhirnya putus sudah harapan untuk mengeyam pendidikan tinggi tersebut. Ironi memang dengan amanat UUD 1945 yang memberikan anggaran $20 \%$ dari Anggaran Pendapatan dan Belanja negara masih banyak orang-orang yang ada di Indonesia putus sekolah atau sekolah hanya sampai dengan SMA yang masih dibawah untuk berkompetitif di dunia kerja.

Alternatif untuk mengatasi masalah tersebut banyak Siswa/i mencari program beasiswa yang sering diberikan oleh lembaga pemerintah, instansi swasta ataupun yayasan yang bergerak dibidang pendidikan, memang untuk mendapatkan beasiswa, Siswa/i harus bekerja keras untuk mendapatkan beasiswa tersebut karena selain yang diberikan beasiswa hanya sedikit, lembaga pemerintah, instansi swasta atau pun yayasan pendidikan memberikan grade yang tinggi untuk penerima beasiswa tersebut, sehingga diharapkan penerima beasiswa tersebut adalah orang-orang yang benar-benar berhak dan layak.

Program Beasiswa untuk mahasiswa baru ini merupakan suatu bantuan yang diberikan kepada mahasiswa mengalami kesulitan ekonomi atau mahasiswa memiliki prestasi yang baik. Besarnya beasiswa yang akan diterima oleh seorang calon mahasiswa baru itu bervariasi, tergantung hasil akhir dari semua tes. Adapun faktor yang mendorong mengapa Universitas Bandar Lampung menerapakan program beasiswa adalah keinginan untuk mencerdaskan masyarakat baik yang berada disekitar UBL maupun diluar UBL. Dalam implementasinya program beasiswa ini mengalami permasalahan yaitu masih sulitnya menentukan besaran persentase penerima beasiswa mahasiswa baru pada Universitas Bandar Lampung khususnya di Fakultas Ilmu Komputer karena tidak adanya pendekatan yang terukur yang digunakan untuk penentuan besaran persentase beasiswa, tidak adanya standar (pedoman) penentuan besaran persentase beasiswa. Berbagai macam pendekatan yang dapat dilakukan untuk penentuan besaran persentase beasiswa, dan Fuzzy Inference System metode MAMDANI adalah salah satu pendekatan yang akan digunakan untuk pemecahan masalah tersebut, sehingga penentuan besaran persentase beasiswa nantinya adalah calon mahasiswa yang benar-benar tepat dan layak untuk mendapatkan beasiswa tersebut. Proses perhitungan menggunakan Fuzzy Inference System (FIS) metode MAMDANI yang terdiri dari Fuzzification, Inference, aplikasi fungsi implikasi dan defuzzification maka penentuan besaran persentase beasiswa akan memberikan hasil yang lebih akurat.

Berdasarkan latar belakang tersebut, maka permasalahan penelitian dibagi menjadi 3 (tiga) yaitu dengan melakukan identifikasi masalah, menentukan ruang lingkup, serta menentukan rumusan masalah.

\subsection{Identifikasi Masalah}

Hasil identifikasi permasalahan dari penelitian ini, yaitu:

a. Sulitnya Menentukan besaran persentase beasiswa untuk mahasiswa baru pada Fakultas Ilmu Komputer UBL.

b. Jumlah beasiswa yang diberikan lebih sedikit dibandingkan dengan calon mahasiswa yang mendaftar untuk mendapatkan beasiswa.

\subsection{Ruang Lingkup Masalah}

Ruang lingkup permasalahan ini hanya dibatasi hanya pada ruang lingkup besaran persentase penerimaan beasiswa mahasiswa baru pada Fakultas Ilmu Komputer Universitas Bandar Lampung Jln.Zainal Abidin Pagar Alam No. 26 Labuhan Ratu Bandar Lampung, dimana variabel yang ada dalam penentuan besaran persentase beasiswa tersebut adalah Nilai test tertulis, Nilai wawancara, Nilai Rapot, Pendapatan Orang Tua dan Pembayaran Rekening Listrik tiap bulannya. Data tersebut merupakan data Semester Ganjil Tahun Ajar 2012/2013 dari Program Studi Teknik Informatika dan Sistem Informasi, untuk output yang diharapkan adalah besarnya persentase yang akan diterima yaitu $10 \%, 25 \%, 50 \%, 75 \%$ dan $100 \%$.

\subsubsection{Tujuan Penelitian}

Keutamaan penelitian ini adalah penerapan algoritmaFuzzy Inference System dengan metode MAMDANIuntuk penentuan besaran persentase beasiswa mahasiswa baru, sehingga beasiswa diterima oleh calon mahasiswa tersebuttepat dan objektif.

\subsubsection{Manfaat Penelitian}

Adapun Luaran yang di dapatkan dari penelitian ini antara lain:

a. Dapat memberikan sumbangan dan memperkaya hasil penelitian yang ada.

b. Dengan adanya algoritma sistem penunjang keputusan yang dibuat dapat membantu dalam penentuan besaran persentase beasiswa dengan tepat sasaran.

c. Sebagai Masukan atau informasi yang bermanfaat bagi Fakultas Ilmu Komputer untuk menentukan besaran persentase beasiswa. 
d. Menambah pengetahuan dalam penerapan konsep Fuzzy Inference System Metode Mamdani di Fakultas Ilmu Komputer Universitas Bandar Lampung.

\section{BAB 2 .LANDASAN TEORI}

\subsection{Fuzzy Logic}

Fuzzy Logic atau Logika Fuzzy dikenalkan pada tahun1965 oleh Lotfi Zadeh, pada tahun 1965 juga Professor Lotfi A Zadeh (Universitas California) diakui sebagai ilmuwan pemerkarsa konsep himpunan fuzzy yang telah menjabarkan perhitungan matematik untuk menggambarkan ketidakjelasan atau kesamaran dalam bentuk variabel linguistik. Ide tersebut dapat diartikan sebagai generalisasi dari teori himpunan klasik yang menggabungkan pendekatan kualitatif dengan kuantitatif. Secara umum Fuzzy Secara umum, logika fuzzy menyediakan struktur inferensi yang memungkinkan kemampuan yang sesuai nalar manusia. (Sivanandam, S. N, Sumathi, S and Deepa, S.N, 2007:p1).

Fuzzy Logic merupakan metodologi yang sangat populer pada saat ini, yang banyak diterapkan dalam aplikasi cybernetics dalam pengembangan program perangkat lunak dan pada saat ini mulai berkembang untuk digunakan dan fuzzy logic dapat dikatakan sebagai suatu alat atau perangkat yang penting untuk memecahkan masalah yang kompleks dan fuzzy logic mempunyai dua karakteristik yang penting yang membuatnya flexsibel dalam penggunaan dalam teknologi yaitu pengguna dapat memilih jumlah kebenaran nilai dari beberapa hal yang tidak terbatas dan yang kedua proses fuzzifikasi dan defuzzifikasi memerlukan semacam nilai kebenaran atau nilai tegas.(Azeem, Fazle 2012:p3-5)

Ada beberapa alasan mengapa kita menggunakan Fuzzy Logic : (Naba Agus, 2009: p3) antara lain :

a. Konsep Fuzzy Logic adalah sangat sederhana hingga mudah dipahami. Kelebihannya dibandingkan konsep yang lain bukan pada kompleksitasnya, tetapi pada naturalness pendekatannya dalam memecahkan masalah.

b. Fuzzy Logic adalah fleksibel, dalam arti dapat dibangun dan dikembangkan dengan mudah tanpa harus memulainya dari "nol".

c. Fuzzy Logic memberikan toleransi terhadap ketidakpresisian data. Hal ini sangat cocok dengan fakta sehari-hari segala sesuatu dialam ini relatif tidak presisi, bahkan meskipun kita lihat/amati secara lebih dekat dan hati-hati. Fuzzy logic dibangun berdasar pada fakta lain. d. Pemodelan/pemetaaan untuk mencari hubungan data input-output dari sembarang sistem black-box bisa dilakukan dengan memakai sistem fuzzy.

e. Pengetahuan atau pengalaman dari para pakar dapat dengan mudah dipakai untuk membangun Fuzzy logic.

f. Fuzzy logic dapat diterapkan dalam desain sistem kontrol tanpa harus menghilangkan teknik desain sistem kontrol konvensional yang sudah terlebih dahulu ada.

g. Fuzzy Logic berdasar pada bahasa manusia.

\subsection{Sistem Fuzzy}

Ada beberapa hal yang perlu diketahui dalam memahami system fuzzy, yaitu (Kusumadewi, Purnomo, 2010:pp6-7):

a. Variable fuzzy, merupakan variabel yang hendak dibahas dalam suatu system fuzzy. Contoh: umur, temperatur, permintaan dan lain sebagainya.

b. Himpunan fuzzy, merupakan suatu grup yang mewakili suatu kondisi atau keadaan tertentu dalam suatu variabel fuzzy.

c. Semesta Pembicaraan, merupakan keseluruhan nilai yang diperbolehkan untuk dioperasikan dalam suatu variable fuzzy. Semesta pembicaraan merupakan himpunan bilangan real yang senantiasa naik (bertambah) secara monoton dari kiri ke kanan. Nilai semesta pembicaraan dapat berupa bilangan positif maupun negative. Adakalanya nilai semesta pembicaraan ini tidak dibatasi batas atasnya. Contoh:

c.1 Semesta pembicaraan untuk variable umur : $[0+\infty]$.

c.2 Semesta pembicaraan untuk variable temperature : [0 40].

d. Domain, merupakan keseluruhan nilai yang diijinkan dalam semesta pembicaraan dan boleh dioperasikan dalam suatu himpunan fuzzy. Seperti halnya semesta pembicaraan, domain merupakan himpunan bilangan real yang senantiasa naik (bertambah) secara monoton dari kiri ke kanan. Nilai domain dapat berupa bilangan positif maupun negative. Contoh domain himpunan fuzzy:
d.1 SANGAT KURANG
$=[0$,
45].
d.2 KURANG
$=$
[46, 59].
d.3 CUKUP
$[60,73]$.
d.4 BAIK
$[74,86]$.
d.5 SANGAT BAIK $=[87,100]$.

2.3 Fungsi Keanggotaan 
Fungsi Keanggotaan (membership function) adalah suatu kurva yang menunjukan pemetaan titik-titik input data kedalam nilai keanggotaannya (sering juga disebut dengan derajat keanggotaan) yang memiliki interval antara 0 sampai 1 (Kusumadewi, Purnomo, 2010, p8-p23). Salah satu cara yang dapat digunakan untuk mendapatkan nilai keanggotaan adalah dengan melalui pendekatan fungsi. Ada beberapa fungsi yang digunakan :

\section{a. Representasi Linear}

Pemetaan input ke derajat keanggotaannya digambarkan sebagai suatu garis lurus. Bentuk ini paling sederhana dan menjadi pilihan yang baik untuk mendekati suatu konsep yang kurang jelas. Ada 2 keadaaan himpunan fuzzy yang linear, yaitu:

1. Representasi Linear Naik, yaitu kenaikan himpunan dimulai pada nilai domain yang memiliki derajat keanggotaan nol [0] bergerak ke kanan menuju ke nilai domain yang memiliki derajat keanggotaan lebih tinggi.

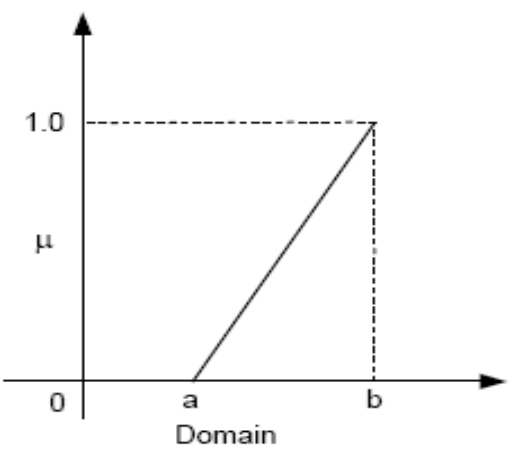

Linier Naik

Gambar 2.2 Representasi Linier Naik

Fungsi keanggotaan:

$$
\mu\left\{\begin{array}{lr}
0 ; & x \leq a \\
\frac{x-a}{b-a} ; & a \leq x \leq b \\
1 ; & x>b
\end{array}\right.
$$

2. Representasi Linear Turun, merupakan kebalikan yang pertama. Garis lurus dimulai dari nilai domain dengan derajat keanggotaan tertinggi pada sisi kiri, kemudian bergerak menurun ke nilai domain yang memiliki derajat keanggotaan lebih rendah.

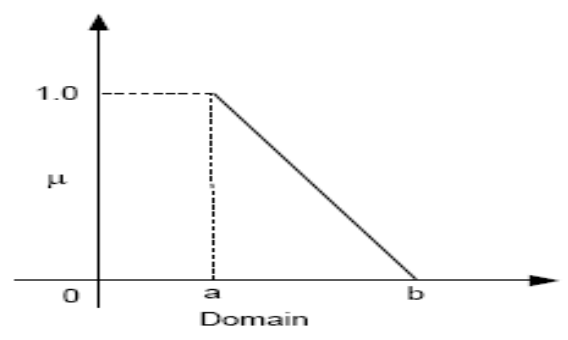

Gambar 2.5 Kurva Trapesium pada gambar dibawah ini :

Gambar 2.4 Kurva Segitiga

\section{Fungsi keanggotaan:}

Gambar 2.3bRepresentasi Linier Turun Fungsi keanggotaan:

$$
\mu\left\{\begin{array}{lr}
\frac{b-x}{b-a} ; & a \leq x \leq b \\
0 ; & x \geq b
\end{array}\right.
$$

\section{b. Representasi Kurva Segitiga}

Kurva Segitiga pada dasarnya merupakan gabungan antara 2 garis (linear) seperti terlihat

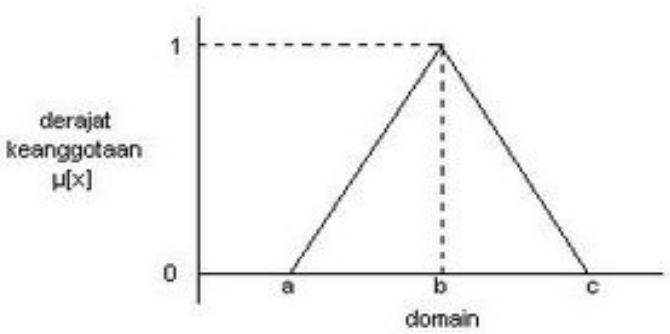

$$
\mu\left\{\begin{array}{lr}
0 ; & x \leq \text { aataux } \geq c \\
\frac{x-a}{b-a} ; & a \leq x \leq b \\
\frac{c-x}{c-b} ; & b \leq x \leq c
\end{array}\right.
$$

\section{c. Representasi Kurva Trapesium}

Kurva Segitiga pada dasarnya seperti bentuk segitiga, hanya saja ada beberapa titik yang memiliki nilai keanggotaan 1 .

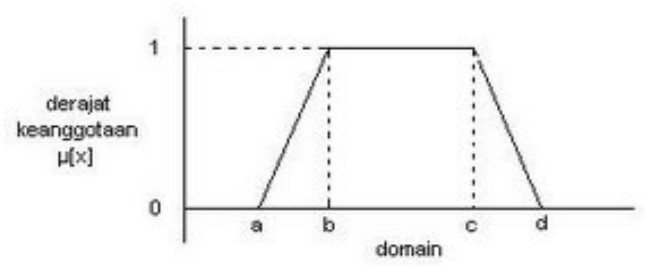

Linier Turun 


\section{Fungsi keanggotaan:}

$$
\mu\left\{\begin{array}{lr}
0 ; & x \leq \text { aataux } \geq d \\
\frac{x-a}{b-a} ; & a \leq x \leq b \\
1 ; & b \leq x \leq c \\
\frac{d-x}{d-c} ; & x \geq d
\end{array}\right.
$$

\section{d. Representasi Kurva Bentuk Bahu}

Daerah yang terletak ditengah-tengah suatu variabel yang direpresentasikan dalam bentuk segitiga, pada sisi kanan dan kirinya akan naik dan turun. Contoh seperti gambar dibawah ini :

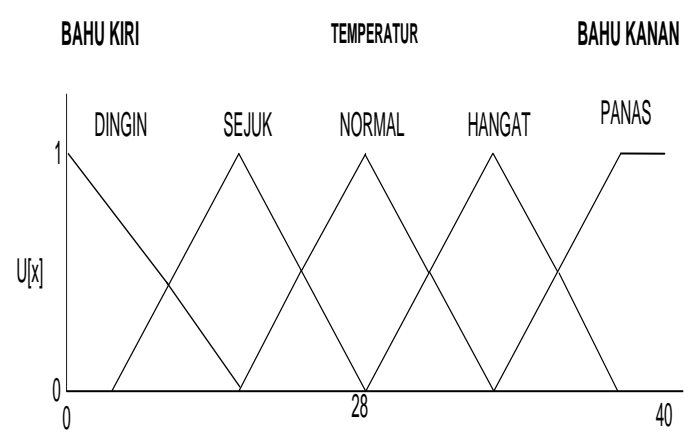

Gambar 2.6 Daerah 'Bahu' pada variabel temperatur

\subsection{Sistem berbasis aturan Fuzzy (Metode MAMDANI)}

Pada sistem berbasis aturan Fuzzy (Fuzzy Inference System) disini penulis menggunakan Metode MAMDANI. Tahap awal pada FIS ini adalah menentikan proses Variabel Linguistik yaitu suatu interval numerik dan mempunyai nilai-nilai linguistik, yang simantiknya didefinisikan oleh fungsi keanggotaannya Sistem berbasis aturan fuzzy terdiri dari tiga komponen utama yaitu : fuzzyfikasi, inference, defffuzifikasi.Metode Mamdani sering dikenal dengan sebagai metode max-min. Metode ini diperkenalkan oleh Ebrahim Mamdani pada tahun 1975. Pada Metode MAMDANI ini, solusi himpunan fuzzy diperoleh dengan cara mengambil nilai maksimum aturan, kemudian menggunakannya untuk memodifikasi daerah fuzzy dan mengaplikasikannya ke output dengan menggunakan operator OR (union). (Suyanto, 2008: p27).

\section{BAB 3. METODE PENELITIAN}

\subsection{Jenis Penelitian}

Jenis Penelitian yang dilakukan oleh penulis adalah Penelitian terapan yaitu dilakukan dengan tujuan dan menerapkan, menguji dan mengevalusi kemampuan suatu teori yang diterapkan dalam memecahkan masalah-masalah praktis.Jadi penelitian murni/dasar berkenaan dengan penemuan dan pengembangan ilmu. Setelah ilmu tersebut digunakan untuk memecahkan masalah, maka peneliti tersebut akan menjadi penelitian terapan.

\subsection{Metode Pengumpulan Data}

Pada Penelitian ini peneliti melakukan beberapa teknik/metode pungumpulan data yaitu :

a. Observasi

Observasi merupakan teknik atau pendekatan untuk mendapatkan data primer dengan cara mengamati langsung objek datanya. Peneliti juga melakukan observasi atau pengamatan untuk memperoleh data dari mahasiswa calon penerima beasiswa tersebut mendaftar sampai dengan test yang terakhir yaitu wawancara.

b. Teknik Wawancara atau Interview

Wawancara (Interview) adalah komunikasi dua arah untuk mendapatkan data dari responden.Pada teknik wawancara ini peneliti melakukan wawancara dengan bagian marketing Fakultas Ilmu Komputer-Universitas Bandar Lampung (UBL) yang bertugas dalam pengrekrutan mahasiswa baru penerima beasiswa serta pihak-pihak yang terkait dalam penerimaan calon mahasiswa baru di Fakultas Ilmu Komputer - Universitas Bandar Lampung.Dari wawancara tersebut didapatkan data-data yang dapat digunakan dalam penelitian ini.

c. Dokumentasi/data arsip

Untuk memperoleh Informasi peneliti juga mencari informasi dari surat, ataupun dokumendokumen yang ada untuk mendapatkan data primer dan sekunder. Dan mengumpulkan data yang sudah diolah didalam databases sebagai data serta informasi didalam penelitian ini.

\subsection{Data Kriteria Fuzzy Logic}

Tabel 3.1

Kriteria Variabel Input dan Output

\begin{tabular}{|c|c|c|}
\hline Kriteria & Keterangan & Fungsi \\
\hline NT & Nilai Test Tertulis & Variabel Input \\
\hline NW & Nilai Wawancara & Variabel Input \\
\hline NR & Nilai Raport & Variabel Input \\
\hline PO & Penghasilan Orang Tua & Variabel Input \\
\hline RL & Rekening Listrik & Variabel Input \\
\hline Beasiswa & Besamya Beasiswa & $\begin{array}{c}\text { Vaniabel } \\
\text { Output }\end{array}$ \\
\hline
\end{tabular}


Dibawah ini adalah data yang diambil dari di Marketing Fakultas Ilmu Komputer Universitas Bandar Lampung Tahun Ajaran Ganjil 2012/2013 untuk memenuhi atribut yang diperlukan. Pada metode penelitian ini diberikan bobot dan atribut yang dibutuhkan untuk menentukan besaran nilai persentase beasiswa. Adapun atributnya, yaitu : Tertulis (NT)

$\mathrm{u}=$ Nilai Variabel input dari Nilai Test $\mathrm{v}=$ Nilai Variabel input dari Hasil dari Wawancara (NW) (NR)

$\mathrm{w}=$ Nilai Variabel input dari Nilai Raport

$\mathrm{x}=$ Nilai Variabel input dari besarnya Penghasilan Orang Tua (PO)

y = Nilai Variabel Output dari Rekening Listrik (RL) Beasiswa

$\mathrm{z}=$ Nilai Variabel Output untuk Besarnya

Dibawah ini merupakan tabel pembobotan Pendapatan orang tua dari variabel Pendapatan Orang Tua, dari setiap Hasil Pendapatan orang tua calon mahasiswa penerima beasiswa dilihat pembobotan nilai dari setiap masing-masing pendapatan orang tua tersebut yang dimiliki oleh setiap calon mahasiswa penerima beasiswa. Semakin kecil penghasilan orang tua yang dimiliki semakin besar point atau nilainya. Nilai tersebut akan digunakan dalam proses fuzzyfikasi

Tabel 3.2 pembobotan Penghasilan Orang Tua

\begin{tabular}{|c|c|c|}
\hline Penghasilan Orang Tua & Point \\
\hline$<500.000$ & 100 \\
\hline & $500.000-<1.000 .000$ & 90 \\
\hline$>1.000 .000-2.000 .000$ & 80 \\
\hline$>2.000 .000-3.000 .000$ & 70 \\
\hline$>3.000 .000$ & 60 \\
\hline
\end{tabular}

Kemudian Data yang dibobotkan berikutnya adalah data Rekening Listrik dari variabel rekening listrik, dan digambarkan dengan tabel 3.3 dibawah ini :

Tabel 3.3 pembobotan Rekening Listrik

\begin{tabular}{|c|c|}
\hline Daya Listrik & Point \\
\hline 450 & 100 \\
\hline 900 & 90 \\
\hline 1300 & 80 \\
\hline$>1300$ & 70 \\
\hline
\end{tabular}

\subsection{Perancangan Penelitian}

Dalam penelitian ini akan dilakukan beberapa tahapan, dimana tahapan ini dapat dilihat pada gambar 3.1, Pada tahapan pertama diawali dengan menentukan kriteria input dan output dari dataset calon penerimaan mahasiswa baru, kemudian dibentuk fuzzyfikasi, setelah melakukan inferensi dengan cara membuat aturan (rules) dan langkah terakhir dihitung defuzzifikasi dari setiap variabel input, dan hasil dari perhitungan defuzzifikasi(menentukan outputcrips). Gambar 3.1 merupakan rancangan tahapan FIS Metode MAMDANI.

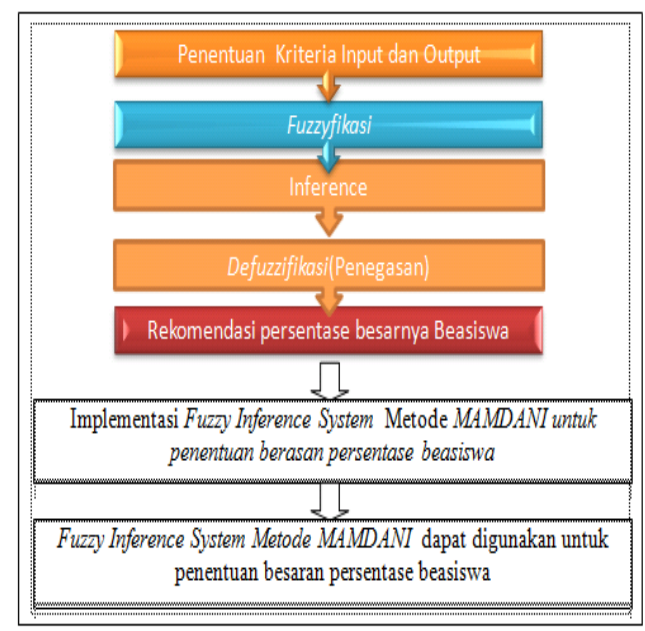

Gambar 3.1

1. Fungsi Keanggotaan Himpunan Fuzzy Input Untuk Nilai Test Tertulis (NT)

Pada Himpunan Fuzzy Nilai Test tertulis (NT) terdapat tiga himpunan fuzzy yaitu Rendah, Sedang, dan Tinggi.Dengan menggunakan 3 fungsi yang digunakan yaitu Representasi Linear Naik, Representasi Linear Turun dan Representasi kurva segitiga. Yang dijelaskan dengan penerapan pendekatan fungsi dan kurva dibawah ini

Rendah :

$\mu \operatorname{rendah}(x)=\left\{\begin{array}{c}\frac{52.5-x}{52.5-33} ; 33 \leq x \leq 52.5 \\ 0 ; \quad x \geq 52.5\end{array}\right.$

Sedang : 


$$
\begin{aligned}
& \mu \operatorname{Sedang}(x) \\
& =\left\{\begin{array}{c}
0 ; x<42.75 \\
\frac{x-42.75}{52.5-42.75} ; 42.75 \leq x \leq 52.5 \\
\frac{62.5-x}{62.25-52.5} ; 52.5 \leq x \leq 62.5 \\
0 ; 62.25 \leq x
\end{array}\right.
\end{aligned}
$$

Tinggi :

$\mu \operatorname{Tinggi}(x)=\left\{\begin{array}{c}0 ; x<52.25 \\ \frac{x-52.25}{72-52.25} ; 52.25 \leq x \leq 72 \\ 1 ; \quad x>72\end{array}\right.$

2. Himpunan Output Fuzzy Untuk Nilai Beasiswa

Pada Himpunan Fuzzy Nilai Beasiswa terdapat lima himpunan fuzzy yaitu Rendah, Agak Sedang, Sedang, Agak Tinggi dan Tinggi. Dengan menggunakan 3 fungsi yang digunakan yaitu Representasi Linear Naik, Representasi Linear Turun dan Representasi kurva segitiga. Yang dijelaskan dengan penerapan pendekatan fungsi dan kurva dibawah ini.

Derajat Keanggotaan Beasiswa terdiri dari :

$$
\begin{array}{r}
\text { Rendah }(10 \%) \\
\mu \operatorname{rendah}(x)=\left\{\begin{array}{c}
\frac{68.75-x}{68.75-63} ; 63 \leq x \leq 68.75 \\
0 ; \quad x \geq 68.75
\end{array}\right.
\end{array}
$$

Agak sedang (25\%)

$$
\begin{aligned}
& \mu \text { Agak Sedang }(x) \\
& =\left\{\begin{array}{c}
0 ; x<63 \\
\frac{x-63}{68.75-63} ; 63 \leq x \leq 68.75 \\
\frac{68.75-x}{74.5-68.75} ; 68.75 \leq x \leq 74.5 \\
1 ; \quad x>74.5
\end{array}\right.
\end{aligned}
$$

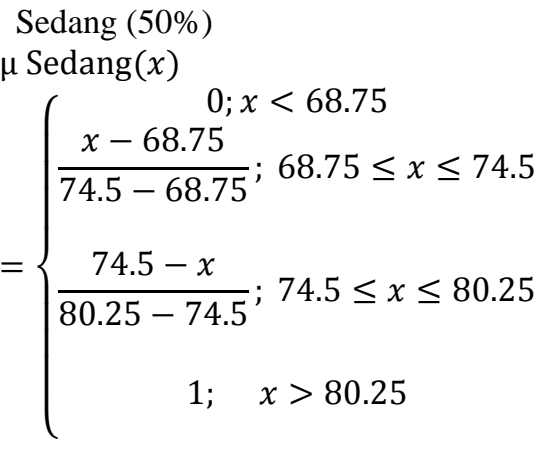

Agak Tinggi (75\%)

$\mu$ Agak Tinggi $(x)$

$$
=\left\{\begin{array}{c}
0 ; x<74.5 \\
\frac{x-74.5}{80.25-74.5} ; 74.5 \leq x \leq 80.25 \\
\frac{80.25-x}{86-80.25} ; 80.25 \leq x \leq 86 \\
1 ; \quad x>86
\end{array}\right.
$$

Tinggi (100\%)

$$
\begin{aligned}
& \text { Tinggi }(100 \%) \\
& \mu \operatorname{Tinggi}(x)=\left\{\begin{array}{cc}
0 ; x<80.25 \\
\frac{x-80.25}{86-80.25} ; 80.25 \leq x \leq 86 \\
1 ; \quad x>86
\end{array}\right.
\end{aligned}
$$

Berikut contoh inferensi aturan dan penggunaan fungsi implikasi pada penentuan beasiswa. Berdasarkan kombinasi variabel input dan himpunan didapat 243 rules yang dapat digunakan. Sebagai contoh digunakan rules 2, rules 15 , rules 30, rules 58 dan rules 234 .

Rules $_{2}: \quad$ IF NT is TINGGI And NW is

\begin{tabular}{|c|c|} 
Aturan/Rule & Persentase \\
\cline { 2 - 2 } & Beasiswa \\
\hline Nilai $>80$ & $100 \%$ \\
\hline$>75$ Nilai $<80$ & $75 \%$ \\
\hline$>73$ Nilai $<75$ & $50 \%$ \\
\hline$>70$ Nilai $<73$ & $25 \%$ \\
\hline$>68$ Nilai $<70$ & $10 \%$ \\
\hline
\end{tabular}

TINGGI And NR is TINGGI And $P O$ is TINGGI And RL is SEDANG THEN BEASISWA is TINGGI 
Rules $_{15}$ : IF NT is TINGGIAnd NW is TINGGI And NR is SEDANG And $P O$ is SEDANG And RL is RENDAH THEN BEASISWA is AGAK TINGGI

Rules 30 : IF NT is TINGGIAnd NW is SEDANG And NR is TINGGI And PO is TINGGI And RL is RENDAH THEN BEASISWA is SEDANG

Rules58: IF NT is TINGGIAnd NW is RENDAH And NR is TINGGI And $P O$ is SEDANG And RL is TINGGI THEN BEASISWA is AGAK SEDANG

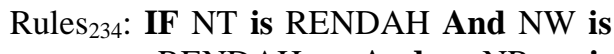
RENDAH And NR is SEDANG And PO is RENDAH And RL is RENDAH THEN BEASISWA is RENDAH

Peritungan FIS Tahap Pertama mencari derajat keanggotaan masing - masing variabel dari contoh kasus 4.

Pada contoh kasus 4 ini, terdapat variabel inputnya yaitu Nilai Test(NT), Nilai Wawancara(NW), Nilai Raport(NR), Nilai Pengahasilan Orang Tua(PO) dan Rekening Listrik(RL). Pada setiap variabel dengan nilai yang ada mempengaruhi himpunan-himpunan yang ada dan sesuai dengan domainnya.

1. Nilai Test $(\mathrm{NT}=48.33)$

Himpunan fuzzy Rendah $\mu_{\mathrm{a}}(48.33)=(48.33-33) / 19.5=0.79$

Himpunan fuzzy Sedang $\mu_{\mathrm{a}}(48.33)=(48.33-42.75) / 9.75=0.57$

2. Nilai Wawancara $(\mathrm{NW}=61.11)$

Himpunan fuzzy rendah $\mu_{\mathrm{a}}(61.11)=(61.11-33) / 28.5=0.99$

Himpunan fuzzy sedang $\mu_{\mathrm{a}}(61.11)=(61.11-47.25) / 14.25=0.97$

3. Nilai Raport $(\mathrm{NR}=76.93)$

Himpunan fuzzy Tinggi $\mu_{\mathrm{a}}(76.93)=(76.93-72.5) / 6.5=0.68$

4. Nilai Penghasilan Orang Tua $(\mathrm{PO}=60)$ Himpunan fuzzy rendah $\mu_{\mathrm{a}}(60)=(60-60) / 20=0.00$

5. Nilai Test $(\mathrm{RL}=100)$

Himpunan fuzzy Tinggi $\mu_{\mathrm{a}}(100)=(100-85) / 15=1.00$
Perhitungan FIS Tahap kedua yaitu menerapkan fungsi implikasi untuk mendapatkan modifikasi output setiap daerah fuzzy dari setiap aturan (rule) yang berlaku. Fungsi implikasi yang digunakan yaitu : metode Min ( $\alpha$-cut). Aturanyang terpengaruh nilai derajat keanggotaan output Beasiswa adalah aturan 115 dan aturan 196.

a. Aturan 115

IF NT is SEDANG And NW is SEDANG

And NR is TINGGI And PO is RENDAH

And RL is TINGGI THEN BEASISWA is AGAK SEDANG

$\alpha_{115}=\mu_{\mathrm{NT}}$ Sedang $\cap_{\mathrm{NW}}$ Sedang $\cap_{\mathrm{NR}}$ Tinggi

$\cap \mu_{\mathrm{PO}}$ Rendah $\cap \mu_{\mathrm{RL}}$ Tinggi $\cap \mu_{\text {Beasiswa }}$ Agak

Sedang

$$
\begin{aligned}
& =\min (0.57 ; 0.08 ; 0.68 ; 1.00 ; 1.00) \\
& =0.08
\end{aligned}
$$

Lihat himpunan Beasiswa Rendah, (a115-63) /

$$
5.75=0.08 \rightarrow \mathrm{a}_{115}=63.46
$$

\section{BAB 4. HASIL DAN PEMBAHASAN}

\subsection{Hasil}

Dalam memperoleh hasil penelitian ini mengenai besaran persentase beasiswa menggunakan Fuzzy Inference System (FIS) MAMDANI telah dilakukan penelitian terkait dengan permasalahan yang ada pada penerimaan mahasiswa beasiswa di Fakultas Ilmu KomputerUniversitas Bandar Lampung

Tabel 4.1 Aturan/Rule Penentuan

Persentase Beasiswa Awal

Pada Tabel 4.3 Data calon penerima beasiswa SMT Ganjil TA 2012/2013 masih terdapat ketidak konsistenan data yang terdapat pada aturan atau rule yang berjalan sekarang pada Fakultas Ilmu Komputer-Universitas Bandar Lampung (UBL), sehingga penulis membuat aturan atau rule yang dapat digunakan untuk memperbaiki sistem yang lama yang dapat dilihat dari Tabel berikut ini :

Tabel 4.2 Aturan/Rule Penentuan Persentase Beasiswa

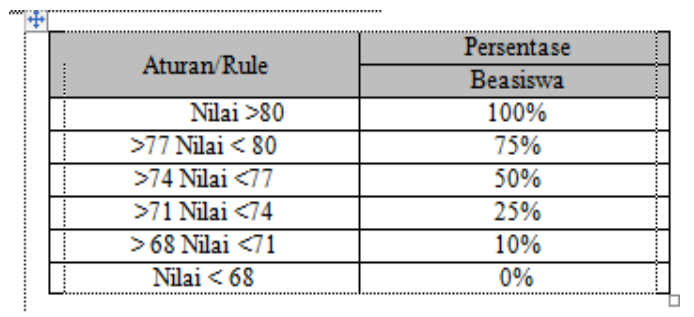

Data diatas adalah data yang diambil secara dari database Marketing Fakuktas Ilmu Komputer. Dari masing-masing bobot tersebut, akan dibuat 
suatu variabel. Dimana dari suatu variabel tersebut akan dirubah kedalam himpunan fuzzy.

Setelah mendapatkan 35 data, data tersebut diujikan dan dimasukan dalam proses atau tahaptahapan pada Fuzzy Inference System Metode MAMDANI yaitu :

a. Pembentukan himpunan fuzzy (Fuzzifikasi)

b. Aplikasi Fungsi Implikasi

c. Komposisi Aturan

d. Defuziffikasi

Setelah hasil akhir didapat pada proses Defuzifikasi kemudian dibandingkan dengan hasil awal apakah sesuai hasil awal dengan hasil yang menggunakan Fuzzy Inference System Metode MAMDANI

\subsection{Pembahasan}

Gambaran Umum data yang digunakan dalam proses Fuzzy Inference System dengan metode Mamdani dapat dilihat dari tabel 4.2 yang merupakan data yang telah dikumpulkan dengan menggunakan teknik pengumpulan data dan data tersebut dipilih dengan menggunakan teknik random simple yaitu pengumpulan data secara acak yang diambil sample sebanyak 35 orang. Data tersebut dibagi menjadi 5 variabel yaitu nilai test tertulis, nilai wawancara, nilai raport, nilai pendapatan orang tua dan nilai rekening listik. Dari 35 data tersebut dicari nilai tertinggi, nilai terendah dan rata-rata yang akan dipergunakan untuk membuat semesta pembicaraan atau domain dari setiap variabel.

Pada tahap ini, Fuzzy Inference System mengambil data input dari database Marketing Fakultas Ilmu Komputer Ganjil TA. 2012/2013 yang kemudian data di oleh menggunakan Matlab dan Microsoft Excel. Tahap pertama (fuzzifikasi) yaitu: menentukan derajat keanggotaanya pada semua himpunan fuzzy menggunakan fungsi keangotaan masing-masing. Pada Tabel 4.5 terdapat lima variabel input yaitu: Nilai Test (NT), Nilai Wawancara (NW), Nilai Raport (NR), Pendapatan Orang Tua (PO) dan Rekening Listrik (RL), dan didapatkan fungsi implikasi pada tabel 4.6 kemudian dibuat Inferensi Rules yang dapat dilihat dari Tabel 3.6 Rules yang didapat dari peluang yang dihasilkan sebesar 243 Rules. Kemudian dengan data-data yang ada dicari fungsi implikasinya setiap data dan nilai $\alpha$-cut kemudian mencari hasil defuzifikasinya dengan menggunakan software matlab.

Tabel 4.3
Hasil Fungsi Keanggotaan fuzzy dengan himpunan fuzzy

\begin{tabular}{|c|c|c|c|c|c|c|c|c|c|c|c|c|c|c|c|}
\hline \multirow{2}{*}{10} & \multicolumn{3}{|c|}{ NI } & \multicolumn{3}{|c|}{$\mathrm{ITW}$} & \multicolumn{3}{|c|}{$\mathbb{R}$} & \multicolumn{3}{|c|}{$\mathrm{PO}$} & \multicolumn{3}{|c|}{$\mathbb{R}$} \\
\hline & $R$ & $s$ & $\mathrm{I}$ & $\mathbb{R}$ & $s$ & I & $\mathbb{R}$ & $s$ & $\mathrm{I}$ & $R$ & $s$ & $\mathrm{I}$ & $R$ & $s$ & I \\
\hline 1 & 0.04 & 0.91 & 0.00 & 0.99 & 0.31 & 0.00 & 0.79 & 0.00 & 0.00 & 0.00 & 0.00 & 0.00 & 0.00 & 0.00 & 1.09 \\
\hline 2 & 0.00 & 0.00 & 0.98 & 0.00 & 0.26 & 0.94 & 0.00 & 0.74 & 0.92 & 0.00 & 0.17 & 1.00 & & 0.00 & $0.0 \%$ \\
\hline
\end{tabular}
keanggotaan dengan himpunan fuzzy didapat, langkah selanjutnya mencari nilai $\alpha$ (Tabel 4.5) untuk masing-masing rules. Nilai $\alpha$ didapat dari nilai minimum pada setiap himpunan fuzzy pada setiap rules. Setelah itu mencari nilai perkiraan (nilai yang ditebalkan pada tabel 4.5). Untuk Nilai $\alpha$ yang akan di cari adalah nilai MIN dan Nilai MAX (himpunan Tinggi dan Rendah). Pada tabel diatas dapat dijelaskan dari setian variabel input yaitu Nilai Test(NT), Nilai Wawancara(NW). Nilai Raport, Pendapatan Orang Tua(PO) dan Rekening Listrik(RL) terdapat 3 Himpunan yaitu rendah, sedang dan tinggi. Nilai-nilai yang ada pada tabel itu didapat dari fungsi derajatan keanggotaan yang terpengaruh.

Tabel 4.4

Range Nilai $\alpha$-cut

\begin{tabular}{|c|c|c|c|c|c|c|c|}
\hline No & $\begin{array}{c}\text { Range } \\
\text { Fuzzy }\end{array}$ & \multicolumn{3}{|c|}{ TINGGI } & \multicolumn{3}{c|}{ RENDAH } \\
\hline 1 & 0.00 & 86 & 86.00 & 5.75 & 63 & 63.00 & 5.75 \\
\hline 2 & 0.01 & 86 & 85.94 & 5.75 & 63 & 62.94 & 5.75 \\
\hline 3 & 0.02 & 86 & 85.89 & 5.75 & 63 & 62.89 & 5.75 \\
in & in
\end{tabular}

berdasarkan nilai data yang paling rendah (minimum) dan nilai data tertinggi (maksimum) dicari nilai perkiraan dari 0 sampai dengan angka 1 sehingga didapat hasil yang ditunjukan oleh tabel 4.7 selanjutnya mencari nilai defuzzifikasi. Proses perhitungan defuzzifikasi menggunakan software MATLAB pada Tabel 4.5.

Tabel 4.5

Rekomendasi Besarnya Persentase Nilai Besaran persentase Beasiswa

\begin{tabular}{|c|c|c|}
\hline \multirow{2}{*}{ No } & \multicolumn{2}{|c|}{ Besaran persentase Beasiswa Seharusnya } \\
\cline { 2 - 3 } & Skor & $\mathbf{\%}$ \\
\hline 1 & 65.18 & $\mathbf{0} \%$ \\
\hline 2 & 68.75 & $\mathbf{1 0} \%$ \\
\hline 3 & 65.18 & $\mathbf{0} \%$ \\
\hline 4 & 68.62 & $\mathbf{1 0} \%$ \\
\hline 5 & 67.89 & $\mathbf{0} \%$ \\
\hline 6 & 75.88 & $\mathbf{7 5} \%$ \\
\hline \multicolumn{3}{|c|}{$\mathbf{1}$ abeı 4.8 merupakan tadeı nası pernıtugan } \\
\hline
\end{tabular}

Defuzzifikasi untuk Rekomendasi Besaran Persentase Nilai Beasiswa pada setiap kasus. Hasil tersebut dicari dengan menggunakan 
software Matlab dengan cara memasukan semua data sample dan kemudian di olah dengan matlab dan didapatkan hasil tersebut yaitu pada kolom skor pada tabel 4.6 Selanjutnya data yang ada pada tabel Tabel 4.6 akan komparasi dengan besaran persentase beasiswa awal.

Tabel 4.6

Perbandingan Nilai Besaran Persentase Beasiswa

\begin{tabular}{|c|c|c|c|c|}
\hline \multirow{2}{*}{ No } & \multicolumn{2}{|c|}{ Besaran Beasiswa Awal } & \multicolumn{2}{c|}{$\begin{array}{c}\text { Besaran Beasiswa } \\
\text { Seharusnya }\end{array}$} \\
\cline { 2 - 5 } & $\%$ & Skor & Skor & $\%$ \\
\hline 1 & $\mathbf{0 \%}$ & 64.47 & 65.18 & $\mathbf{0} \%$ \\
\hline 2 & $\mathbf{1 0 0} \%$ & 81.81 & 68.75 & $\mathbf{1 0} \%$ \\
\hline 3 & $\mathbf{0 \%}$ & 60.47 & 65.18 & $\mathbf{0} \%$ \\
\hline 4 & $\mathbf{1 0} \%$ & 69.28 & 68.62 & $\mathbf{1 0} \%$ \\
\hline 5 & $\mathbf{5 0} \%$ & 73.55 & 67.89 & $\mathbf{0} \%$ \\
\hline 6 & $\mathbf{2 5} \%$ & 70.92 & 75.88 & $\mathbf{7 5} \%$ \\
\hline 7 & $\mathbf{1 0} \%$ & 69.03 & 65.37 & $\mathbf{0} \%$ \\
\hline 8 & $\mathbf{1 0 0} \%$ & 81.28 & 68.75 & $\mathbf{1 0} \%$ \\
\hline 9 & $\mathbf{2 5} \%$ & 70.17 & 67.79 & $\mathbf{0} \%$ \\
\hline 10 & $\mathbf{5 0} \%$ & 73.92 & 70.36 & $\mathbf{2 5} \%$ \\
\hline
\end{tabular}

Pada tabel 4.9 Besaran Persentase Nillai Beasiswa dikomparasi dengan besaran persentase beasiswa awal pada setiap kasus. Pada kolom besaran persentase beasiswa awal merupakan hasil awal pada penentuan besaran persentase beasiswa dan dibandingkan pada kolom besaran persentase beasiswa seharusnya yaitu adalah hasil yang didapat dengan proses deffuzifikasi dengan menggunakan MATLAB kemudian kedua hasil tersebut dikomparasi untuk tahap selanjutnya akan dilakukan uji analisis hasil komparasi.

Tabel 4.7

Analisis Komparasi Hasil Inferensi MAMDANI untuk nilai besaran persentase Beasiswa dengan penentuan awal

\begin{tabular}{|c|c|c|c|}
\hline \multirow{2}{*}{ No } & $\begin{array}{c}\text { Besaran } \\
\text { Beasiswa Awal }\end{array}$ & $\begin{array}{c}\text { Besaran } \\
\text { Beasiswa Seharusnya }\end{array}$ & \multirow{2}{*}{ Status } \\
\cline { 2 - 3 } & $\%$ & $\%$ & \\
\hline 1 & $0 \%$ & $0 \%$ & SESUAI \\
\hline 2 & $100 \%$ & $10 \%$ & TIDAK SESUAI \\
\hline 3 & $0 \%$ & $0 \%$ & SESUAI \\
\hline 4 & $10 \%$ & $10 \%$ & SESUAI \\
\hline 5 & $\mathbf{5 0} \%$ & $0 \%$ & TIDAK SESUAI \\
\hline
\end{tabular}

seteıаn aıакикаn ujı коmparası paaa tab́el 4.8 kemudian hasil analisis didapat pada Tabel 4.9, yaitu besaran persentase beasiswa pada beassiwa awal dengan besaran persentase beasiswa seharusnya yang dilakukan dengan menggunakan Fuzzy Inference System Metode Mamdani, sehingga dapat diketahui sesuaian nilai besaran persentase awal dan nilai dengan meggunakan metode MAMDANI.

\section{BAB 5. KESIMPULAN DAN SARAN 5.1 Kesimpulan}

Berdasarkan penelitian yang dilakukan dengan penerapan FIS Metode MAMDANI, maka dapat disimpulkan bahwa: FIS Metode MAMDANI dapat digunakan untuk penentuan besaran persentase beasiswa pada Fakultas Ilmu Komputer-Universitas Bandar Lampung. Dengan adanya penerapan FIS Metode MAMDANI, dapat mempermudah top management di Fakultas Ilmu Komputer-Universitas Bandar Lampung untuk mengambil keputusan penentuan besaran persentase beasiswa pada calon mahasiswa penerima beasiswa dengan tepat dan objektif.

Adapun tahap-tahapan proses dalam penentuan besaran persentase beasiswa ini dengan menggunakan Fuzzy Inference System (FIS) dengan menggunakan Metode MAMDANI adalah Sebagai Berikut :

a. Pembentukan himpunan fuzzy (Fuzzifikasi)

Pada Tahap ini dalam penentuan besaran persentase beasiswa ini mengambil variabel input yang ada dan menentukan keanggotaan dari setiap variabel, pada himpunan ini terdapat 5 variabel inputyaitu :

1. Nilai Test (NT)

2. Nilai Wawancara $(\mathrm{NW})$

3. Nilai Raport (NR)

4. Nilai Pendapatan Orang Tua (PO)

5. Nilai Rekening Listrik (RL)

Sedangkan variabel output adalah Beasiswa. Pada Penelitian ini terdiri dari 3 Himpunan yaitu :

1. Rendah

2. Sedang

3. Tinggi

Dan kemudian dari setiap variabel input dan input ditentukan semesta pembicaraan atau domain. Kemudian dibuat kurva dari setiap himpunan dan variabel input dan output.

b. Aplikasi Fungsi Implikasi

Pada Tahap ini di masukan nilai-nilai dari setiap input variabel berdasarkan himpunan yang ada. Pada penelitian ini digunakan metode minimum untuk mengkombinasikan setiap derajat keanggotaan dari setiap rules yang dibuat, pada tahap ini dari kombinasi 3 Himpunan dan 5 Variabel Input, terbentuk 243 rules yang berpengaruh.

\section{c. Komposisi Aturan}

Pada saat komposisi aturan ini ditentukan rules yang berpengaruh, pada tahap ini digunakan metode Max(Maximum) dari setiap kasus.

\section{d. Defuziffikasi}

Pada tahap ini nilaicrisp output berupa besaran persentase beasiswa yang paling sesuai dengan cara mengubah cripsinput yaitu : berupa himpunan fuzzy yang diperoleh dari komposisi aturan-aturan fuzzy menjadi suatu bilangan pada domain himpunan fuzzy tersebut. 


\subsection{Saran}

Berdasarkan hasil penelitian yang dilakukan penulis, maka dapat diusulkan beberapa saran, sebagai berikut :

a. Algoritma dari penerapan Fuzzy Inference System metode MAMDANI untuk penentuan besaran persentase beasiswa ini dapat diimplementasikan sebagai sistem penunjang keputusan pada Fakultas Ilmu KomputerUniversitas Bandar Lampung.

b. Algoritma dari penerapan Fuzzy Inference System metode MAMDANI untuk penentuan besaran persentase beasiswa dalam penelitian ini dapat dikembangkan dalam bentuk rancangan antar muka atau program aplikasi yang dapat diimplementasikan pada Fakultas Ilmu KomputerUniversitas Bandar Lampung.

c. Dapat dilakukan penelitian pengembangan dengan pendekatan lain dengan fuzzy inference system dengan metode yang lain seperti Tsukamoto atau Sugeno.

d. Karena Pewawancara masih bersifat subjektif dibutuhkan pewawancara yang mempunyai integritas dan tidak mempunyai konflik kepentingan dalam program beasiswa ini.

\section{DAFTAR PUSTAKA}

1) Azeem, Fazle (2012),'Fuzzy Inference System - Theory and Applications". Croatia : InTech Croatia

2) Kusumadewi, S, dan Purnomo, H. (2010). "Aplikasi Logika Fuzzy untuk Pendukung Keputusan", Graha Ilmu, Yogyakarta.

3) Naba, Agus, Dr. Eng. (2009).'Belajar Cepat Fuzzy Logic menggunakan MATLAB”, Yogyakarta:Andi.

4) Sivanandam, S.N, Sumathi, S dan Deepa, S.N (2007). "Introduction to Fuzzy Logic using MATLAB”.Germany :Springer Berlin Heidelberg New York.

5) Sugiyono (2012)."Metode Penelitian Kuantitatif Kualitatif dan R\&D”, AlfaBeta, Bandung.

6) Undang-Undang Republik Indonesia Tahun 2012 Tentang Pendidikan Tinggi.

7) William Siler and James J. Buckley(2005), "Fuzzy Expert Systems
And Fuzzy Reasoning”, Published simultaneously in Canada. 